\title{
Equilibrium
}

Quarterly Journal of Economics and Economic Policy

VOLUME 8 ISSUE 3, 2013

ISSN 1689-765X, (Online) ISSN 2353-3293

http://www.equilibrium.umk.pl/

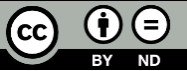

Cieślik A., Rokicki B. (2013), Regional Structure of Wages in Poland Over the Period 1995-2009, "Equilibrium. Quarterly Journal of Economics and Economic Policy”, Volume 8, Issue 3, pp. 65-78, DOI: http://dx.doi.org/10.12775/EQUIL.2013.020

\author{
Andrzej Cieślik \\ Bartłomiej Rokicki* \\ University of Warsaw, Poland
}

\section{Regional Structure of Wages in Poland Over the Period 1995-2009**}

JEL Classification: $J 31, R 12$

Keywords: core-periphery, regional wages, Poland

\begin{abstract}
In this paper, we test empirically for the increasing returns-based agglomeration and investigate the impact of the economic integration with the European Union on regional wage inequalities in Poland. In our study, we use the wage data for 16 Polish regions over the period of 1995-2009. Our results are consistent with the predictions of the core-periphery models of the New Economic Geography. In particular, we find that wages decrease as one moves away from the Mazowiecki capital region, as well as from the border with Germany.
\end{abstract}

(C) Copyright Institute of Economic Research \& Polish Economic Society Branch in Torun Date of submission: February 28, 2013; date of acceptance: August 18, 2013

* Contact: cieslik@wne.uw.edu.pl, brokicki@wne.uw.edu.pl, Department of Macroeconomics and International Trade Theory, Faculty of Economic Sciences, University of Warsaw, ul. Długa 44/50, PL-00-241 Warszawa, Poland

${ }^{* *}$ This research has been financed by the Polish National Science Centre under the project 2011/03/B/HS4/05681.

The authors would like to thank two anonymous referees for their comments and suggestions on the previous version of this paper. 


\section{Introduction}

The phenomenon that regional economic development is unequal has long been recognized by economists. ${ }^{1}$ However, for many years economists were experiencing difficulties in explaining why regional income disparities may exist on the grounds of the neoclassical theory. The emergence of the "New Economic Geography" (NEG) literature in the early 1990s allowed for formal modeling of regional disparities using the tools borrowed from the "New Trade Theory" (NTT), based on increasing returns and imperfect competition developed in the late 1970s and the early 1980s.

In particular, in his seminal paper Krugman (1991) pointed out that economic agglomeration is very much an economic phenomenon, and so are regional income disparities. ${ }^{2}$ Since then, the study of economic geography has been occupying an increasing part of the mainstream economic analysis. The Core-Periphery (CP) structure of the economy is one of the most widely studied in the field of the New Economic Geography. The intuition behind the CP model is summarized by Combes et al. (2008, p.130): "economic activities are concentrated in a limited number of regions, which form the core of a civilization, while the other regions stagnate, or even regress, and these are known as the periphery".

In the recent years, the relationship between regional economic integration and the location of economic activity inside integrating countries has become one of the most important issues on the research agenda of the NEG literature. However, the existing theoretical studies are not clear about this relationship, and often yield conflicting predictions.

In particular, Krugman and Livas-Elizondo (1996) argued that closed markets promote huge central metropolises, while open markets discourage them. Their argument was inspired by the case of Mexico, where the capital is one of the world's most populous cities, but the country has begun a noticeable process of decentralization as it liberalizes trade. According to their model's predictions, a decrease in international transaction costs between the integrating countries may foster the dispersion of economic activity within liberalizing countries. However, subsequent studies by Monfort and Nicolini

\footnotetext{
${ }^{1}$ See the examples of the so-called 'High development theory' of the late 1950s such as the early works of Myrdal (1957) and Hirschmann (1958).

${ }^{2}$ He developed a core-periphery model based on increasing returns to scale in production. According to him in order to realize scale economies while minimizing transport costs, manufacturing firms tend to locate in the region with larger demand, but the location of demand itself depends on the distribution of manufacturing. Once firms are agglomerated in an industry center, subsequent entrants also prefer the industry center to alternative locations since it offers the least-cost site from which to serve the broader market.
} 
(2000), Alonso-Villar (2001), Paluzie (2001) and Crozet and KoenigSoubeyran (2004) show that this original result may not be robust.

The aforementioned studies show that when regions have symmetric access to the rest of the world, external trade liberalization is expected to enhance agglomeration of economic activity inside the country that is opening to trade. Conversely, when regions have different access to international markets, trade liberalization generally favors the border regions. The latter conclusion seems to be supported by empirical studies on the impact of North American integration process on the location of economic activity in Mexico. For example, Hanson $(1997,2001)$ finds that many industries were leaving Mexico City in favor of regions located closer to the US border.

In this study, we follow Hanson's (1997) approach to test empirically the two main predictions of the NEG models for Poland. In particular, Hanson (1997) tested the increasing returns and the effect of trade reform on regional wages in Mexico. We perform a similar analysis for Poland during the 19952009 period using the data on average regional wages. Our main findings concerning the role of increasing returns are consistent with the predictions of the theory, while for the impact of the European integration on the wage compression only some limited evidence has been found.

The reminder of this paper is organized as follows. In the next section, we summarize the main findings of Hanson's (1997) paper, with special attention devoted to the theoretical predictions of the NEG models for the regional structure of wages. Then, we describe the Polish trade policy and some of the Polish regional characteristics. After the description of the dataset, our empirical results follow. We conclude with policy guidelines and directions for further studies.

\section{Literature Review}

According to Hanson (1997), empirical identification of agglomeration effects is generally a difficult task. The standard approach to identify the agglomeration effect is to use a measure of local economic activity, such as value added or employment, as an independent variable in the estimating equation. In his paper, Hanson (1997) tested empirically for the agglomeration effects, taking advantage of the implications increasing returns have for the regional structure of wages. In particular, he argued that firms that locate in more densely populated regions must compensate workers by paying them higher wages. Although other exogenous site-specific characteristics may matter for wages, but only with low probability they will cause wages to decline with distance from the centers of economic activity. 
The approach proposed by Hanson (1997) requires not only that wages are correlated with agglomeration, but that wages decrease monotonically as one moves away from the economic center. In particular, he tested two main predictions of the CP model:

- industry concentrates geographically and relative wages decrease with transport costs from industry centers,

- a reduction of trade barriers is likely to compress regional wage differentials.

Hanson (1997) studied both the pre- and post-trade reform regional wage structure for Mexico using aggregated by industry regional average wages. He postulated that trade liberalization increases foreign demand relative to domestic demand, weakening the effects of the domestic industry center. In the case of Mexico, as a result of trade reform, firms from the industry center located in the Mexico city tended to move closer to the US border, thus congestion costs in the capital region would fall, and so a fall in nominal wages in Mexico relative to other regions could be observed.

Hanson (1997) used a simple econometric equation for testing for increasing returns and the effect of the trade reform in Mexico. He regressed regional wages as a percentage of the average wage in the capital on transport costs from the capital and from the US border. As for the proxy of the transportation costs he used two distance variables: the distance from the US border and the distance from Mexico city. Hanson's (1997) study provided empirical evidence that the states with the highest wages were located near Mexico City or along the US-Mexico border, while the states with lowest wages were those proximate neither to the capital nor the United States. Testing for the effect of trade reform yielded only weak evidence for a compression in regional wage differentials following the trade reform.

According to the best of our knowledge, the spatial differences in the Polish labor market so far have not been very extensively investigated, especially in the context of the NEG models. In terms of wages, regional differences in Poland were studied previously by Adamczyk et al. (2009), Misiak et al. (2011), Rogut and Tokarski (2007), Rokicki (2007), and more recently by Cieślik and Rokicki (2013). Yet, only the last study compares the empirical results with the theoretical previsions of the NEG models. In what follows, we formally test the predictions of the NEG models for Poland, applying the econometric equation proposed by Hanson (1997). 


\section{Polish Foreign Trade Policy and the EU Accession}

Prior to the 1990s Poland had a relatively closed economy towards the West and traded mainly with the countries of the former Council of Mutual Economic Assistance (CMEA). Starting from 1989 Poland has undergone a major macroeconomic and structural adjustment in its transition to a market economy. Under extremely difficult economic and social circumstances, notably the collapse of trade with the former Eastern-block countries and the consequent initial job losses, the subsequent governments have largely resisted protectionist pressures (WTO 2000).

From the early 1990s, new trade opportunities with the West started to open up, especially with the European Union and the European Free Trade Association (EFTA). In 1991 Poland signed the association agreement with the EU that entered into force in 1994, but trade liberalization started as early as in 1992 within the framework of the Interim Agreement. Trade in industrial products with the EU was liberalized completely by 2001, while trade in agricultural products only with the accession to the EU in 2004. When Poland joined the EU on the 1st of May 2004 all the remaining trade barriers towards the European Union were eliminated.

In the early 1990s Poland started to liberalize its trade also with other European countries in the form of both regional free trade agreements and bilateral agreements. The association agreement with the EU was complemented by the similar agreement with the EFTA countries signed in 1992, which entered into force in 1993. This agreement liberalized trade in industrial products and excluded agricultural products.

Starting from 1992, Poland started to liberalize its trade also with the new EU member states: in particular with the Czech Republic, Hungary and Slovakia within the framework of the Central European Free Trade Area (CEFTA), as well as with the Baltic States within the framework of bilateral free trade agreements. Similarly to the case of trade liberalization with the EU and the EFTA countries, those agreements liberalized trade of manufactured products. ${ }^{3}$

On May 1, 2004 when Poland and other Central and East European countries (CEECs) have joined the European Union, international transaction costs have effectively disappeared along their Western frontiers, while along their Eastern borders they increased or remained unchanged in absolute terms, and increased in relative terms. This asymmetric trade liberalization and the adoption of the common EU external trade policy may increase re-

\footnotetext{
${ }^{3}$ See for details Cieślik (2007) and Cieślik and Hagemejer (2011).
} 
gional disparities across regions of the new member states, as they do not have the same access to foreign markets. Many new member states fear that increased economic integration will result in regional divergence and income polarization leading to internal tensions and adding more pressure on the EU budget, where regional policies have always ranked high on the political agenda. Therefore, it is crucial to investigate whether and how the economic integration of the CEECs with the EU affects the internal geography of these countries.

Although the trade liberalization process in Poland was relatively long and cannot be connected only with the year 2004 when Poland joined the $\mathrm{EU}$, we are going to test for the effect of the EU accession, which gave an additional stimulus to the development of Polish foreign trade. Hence, we use this date so as to test for the change in the structure of regional wages as the result of the wider opening the borders with the EU countries.

\section{Polish Regional Characteristics}

On one hand, mainly because of historical reasons, in the Western parts of Poland the standards of living and wages are higher and the unemployment rate is lower than in the Eastern regions. On the other hand, the large fraction of the economy is concentrated in the Mazowiecki region, where the capital of Poland, Warsaw, is located. The capital region has the highest wages and the lowest unemployment rate in the country.

Figure 1 shows the time series of average real regional wages (in PLN) over the 1995-2009 period. In this period, wages have increased in every Polish region. However, there is a clear contrast between the Mazowiecki region and the other regions. In the last fifteen years, the regional wage differentials have increased as the Mazowiecki has experienced a higher wage growth rate than other regions, which was mainly driven by increasing wages in the capital city. We can see from Figure 1 that the difference somewhat lessened after 2005, but later those differences increased even further. 
Figure 1. Evolution of regional market economy wages between 1995 and 2009

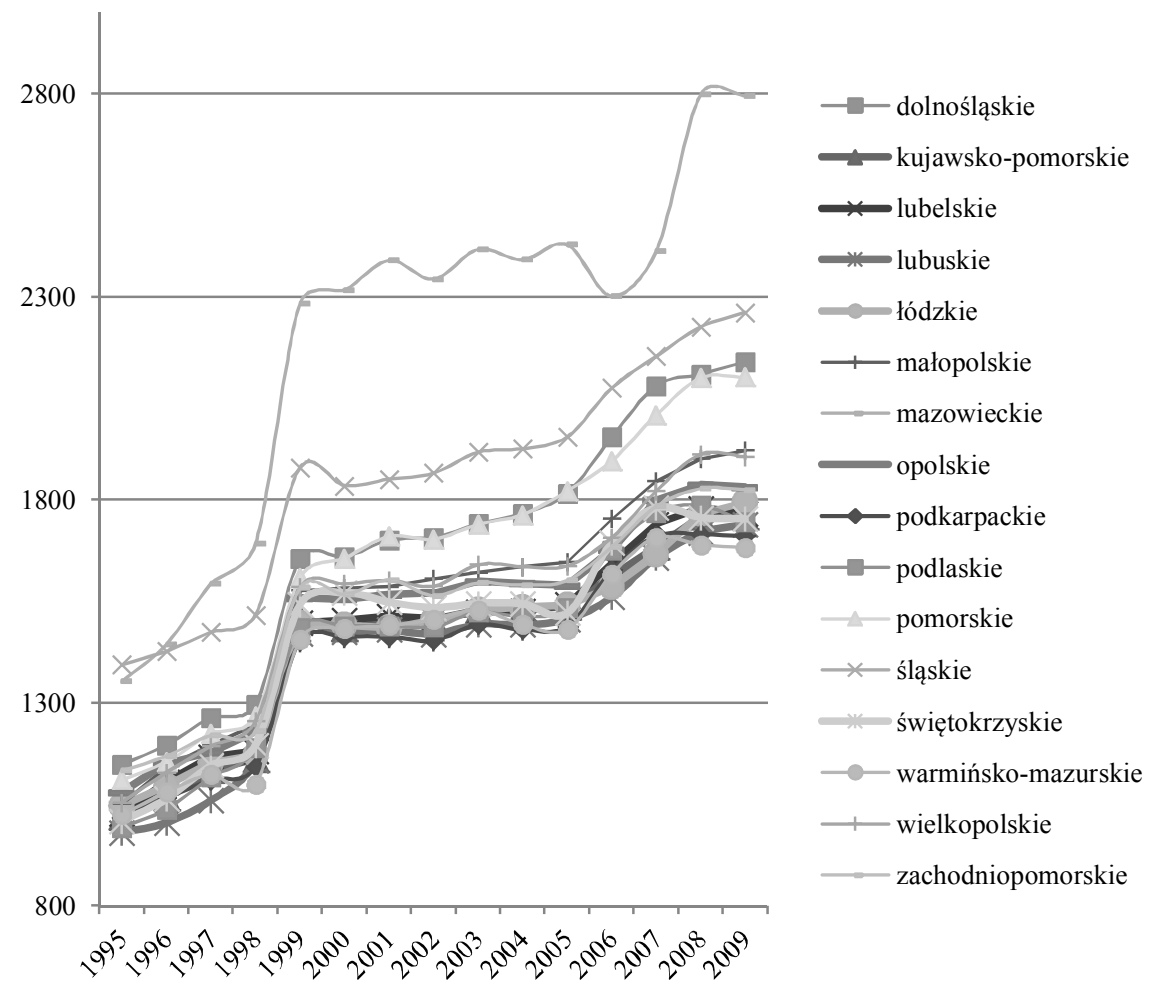

Source: own elaboration on the basis of the CSO data.

Figures 2 and 3 show the maps of the Polish road and railways network. It can be easily noted that in the western parts of the country, especially near the border with Germany, the density of the railway and road networks is higher compared to the eastern parts of the country. The capital city in located almost in the heart of the country's railway and road networks, allowing firms located in Warsaw to access the country's major regional markets. In addition, the concentration of roads around other major cities such as Poznań, Wrocław, and Katowice can be observed. 
Figure 2. Railway network in Poland

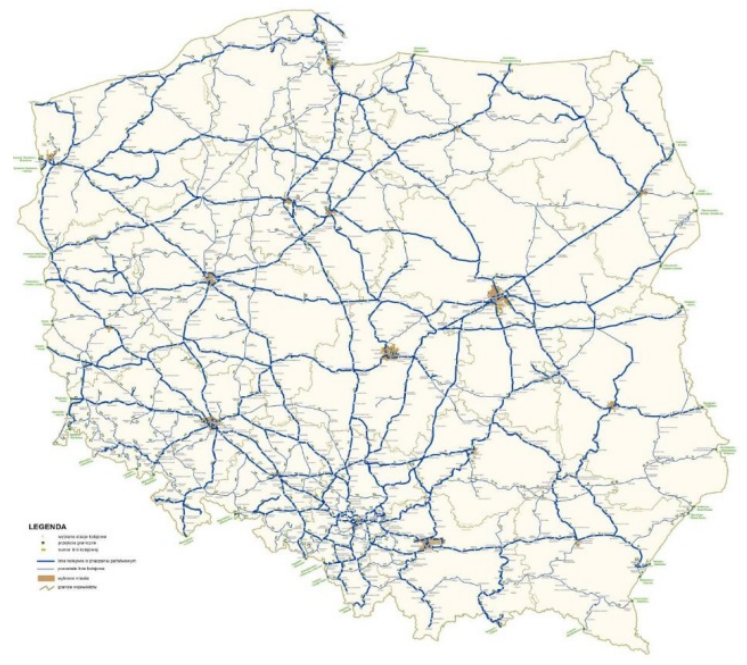

Source: PKP PLK S.A. Biuro Nieruchomości i Geodezji Kolejowej. Warszawa 2012.

Figure 3. Road network in Poland

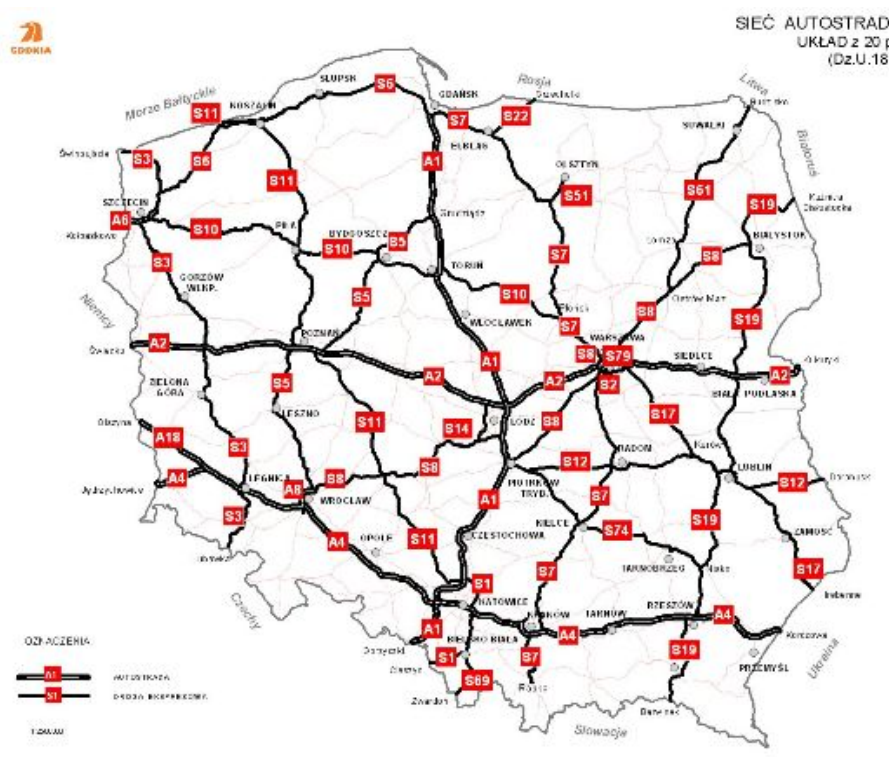

Source: Generalna Dyrekcja Dróg Krajowych i Autostrad. 


\section{Empirical Methodology and Statistical Data}

In our study we focus on the average nominal wages at the regional level. We use the wage data from the Polish Local Database (Bank Danych Lokalnych) for the period of 1995-2009. Our database differs from that database of Hanson (1997) used for Mexico. In particular, we use regional average wage data for 16 Polish regions, while Hanson used data for 31 Mexican regions. On the other hand, Hanson (1997) used data aggregated not only by state but also by industry, while industry-region level data unfortunately was not available for Poland. ${ }^{4}$

Following Hanson's (1997) approach, we use two distance variables: the distance from the capital, and the distance from the German border as proxies for the transportation cost. In Table 1, the summary statistics of the variables (in logs) used in this study are provided.

Table 1. Summary statistics

\begin{tabular}{|l|c|c|c|c|c|}
\hline \multicolumn{1}{|c|}{ Variable } & Observations & Mean & Std. Dev. & Min & Max \\
\hline $\log (\text { relative wages })^{\prime}$ & 240 & -0.334726 & 0.128506 & -0.5071957 & 0.0296051 \\
\hline $\log \left(\right.$ WAR $\left._{i}\right)$ & 240 & 5.197951 & 1.385835 & 0 & 6.194793 \\
\hline $\log \left(G E R_{i}\right)$ & 240 & 5.601657 & 0.9849444 & 2.564949 & 6.496775 \\
\hline $\log \left(\text { WAR }_{i}\right)^{*}$ BORDER $_{i}$ & 240 & 1.125567 & 2.349021 & 0 & 6.194793 \\
\hline $\log \left(G E R_{i}\right) * B O R D E R_{i}$ & 240 & 0.7367382 & 1.602681 & 0 & 5.111988 \\
\hline $\log \left(\text { WAR }_{i}\right)^{*} E U_{t}$ & 240 & 2.07918 & 2.698117 & 0 & 6.194793 \\
\hline $\log \left(G E R_{i}\right)^{*} E U_{t}$ & 240 & 2.240663 & 2.819647 & 0 & 6.496775 \\
\hline $\log \left(\text { WAR }_{i}\right)^{*}$ BORDER $_{i}{ }^{*} E U_{t}$ & 240 & 0.4502268 & 1.585083 & 0 & 6.194793 \\
\hline $\log \left(G E R_{i}\right) * B O R D E R_{i} * E U_{t}$ & 240 & 0.2946953 & 1.076219 & 0 & 5.111988 \\
\hline
\end{tabular}

Source: own calculation.

As compared with Hanson's (1997) analysis of the Mexican data, Poland is a smaller country and so there are also smaller distances than in Mexico. Despite the difference in the size of the country, and in particular distances within the country, some similarities between these two countries with respect to the concentration of wages can be observed. For example, in Hanson's study the average Mexican relative wage proportion was 0.648 , while in Poland it was 0.722 .

\footnotetext{
${ }^{4}$ In his second set of regressions Hanson (1997) used data only for the manufacturing industries.
} 
We estimate the relative wages as a function of transport costs (distances) and trade policy variables. As for the measure of transport costs we use two distance variables: the distance from Warsaw and the distance from the German border measured in kilometers. To control for the presumably different behavior of the EU-border regions we include dummy variables for these regions. ${ }^{5}$ So as to test for the effect of joining the European Union in 2004 we also include a dummy indicating that the year is after 2004 .

We estimate the following equation:

$\log \left(W A G E_{i t} / W A G E_{W A R t}\right)=\beta_{0}+\beta_{1} \log \left(W A R_{i}\right)+\beta_{2} \log \left(G E R_{i}\right)+$ $\beta_{3} \log \left(W A R_{i}\right) * B O R D E R_{i}+\beta_{4} \log \left(G E R_{i}\right) * B O R D E R_{i}+\beta_{5} \log \left(W A R_{i}\right) * E U_{t}+$ $\beta_{6} \log \left(G E R_{i}\right) * E U_{t}+\beta_{7} \log \left(W_{A}\right) * B O R D E R_{i} * E U_{t}+\beta_{8} \log \left(G E R_{i}\right) * B O R D E R_{i}$ ${ }^{*} E U_{t}+u_{i}+v_{t}+\varepsilon_{i t}$

where: $W A G E_{i t}$ is an average wage in region i at time t, $W A G E_{W A R t}$ is an average wage in Warsaw region at time t, $W A R_{i}$ is a unit transport cost from region i to Warsaw, $G E R_{i}$ is a unit transport cost from region $\mathrm{i}$ to the border with Germany, $B O R D E R_{i}$ is a dummy variable that takes value one if the region is located at the border and the neighboring country is an EU member country, $E U_{t}$ is a dummy variables equal to one after 2004 (the date of joining the EU), $u_{i}$ is a region-specific effect, $v_{t}$ is an individual time effect and $\varepsilon_{i t}$ is an error term that satisfies the standard properties.

The above equation was estimated using the pooled OLS estimation technique. This equation yields unbiased parameter estimates if the error term $\left(\varepsilon_{\mathrm{it}}\right)$ is uncorrelated with the explanatory variables. The unobserved components affecting regional wages are not correlated with the distance from Warsaw and the distance from Germany. Other, unobserved regional characteristics which can probably affect regional wages can be natural resource supplies, amenities or the government's regional policy. For example, some locations might be attractive to live and work because they offer nice places or the weather is better. If these amenities are important for workers then, other things equal, they will be willing to accept lower wages in the high amenity locations. In the case of Poland, we can assume that these are not correlated with distances.

${ }^{5}$ For example, these regions are more likely to receive FDI. See for details Cieślik (2005a,b) and Cieślik (2013). 


\section{Estimation Results}

The main prediction of the NEG models is that the estimated coefficients on WAR and GER variables should be negative. As for the impact of EU accession on wages we test for the significance of the estimated parameters $\beta_{5}-\beta_{8}$ on variables including the EU term in our equations. The estimation results are reported in Table 2 .

Table 2. Pooled OLS estimation results

(heteroscedasticity-consistent, cluster robust standard errors in parentheses).

\begin{tabular}{|c|c|c|c|c|c|}
\hline VARIABLES & (1) & (2) & (3) & (4) & (5) \\
\hline Constant term & $0.21^{* * *}$ & $0.22^{* * *}$ & $0.60^{* * *}$ & $0.60^{* * *}$ & $0.55^{* * *}$ \\
\hline $\log \left(W A R_{i}\right)$ & $\begin{array}{c}-0.06 * * * \\
(0.008)\end{array}$ & $\begin{array}{c}(0.080) \\
-0.06^{* * *} \\
(0.007)\end{array}$ & $\begin{array}{c}(0.194) \\
-0.06 * * * \\
(0.007)\end{array}$ & $\begin{array}{c}(0.192) \\
-0.06 * * * \\
(0.006)\end{array}$ & $\begin{array}{c}(0.024) \\
-0.07 * * * \\
(0.001)\end{array}$ \\
\hline $\log \left(G E R_{i}\right)$ & $\begin{array}{c}-0.02 \\
(0.013)\end{array}$ & $\begin{array}{l}-0.02 * \\
(0.012)\end{array}$ & $\begin{array}{l}-0.08 * * \\
(0.031)\end{array}$ & $\begin{array}{l}-0.08 * * \\
(0.031)\end{array}$ & $\begin{array}{c}-0.07 * * * \\
(0.003)\end{array}$ \\
\hline $\log \left(W A R_{i}\right) * E U_{t}$ & & $\begin{array}{l}-0.00 \\
(0.002)\end{array}$ & & $\begin{array}{c}-0.00 \\
(0.008)\end{array}$ & $\begin{array}{l}-0.00 \\
(0.003)\end{array}$ \\
\hline $\log \left(G E R_{i}\right) * E U_{t}$ & & $\begin{array}{c}0.00 \\
(0.005)\end{array}$ & & $\begin{array}{l}-0.00 \\
(0.031)\end{array}$ & $\begin{array}{l}-0.00 \\
(0.010)\end{array}$ \\
\hline $\log \left(W A R_{i}\right) * B O R D E R_{i}$ & & & $\begin{array}{r}-0.08 * * \\
(0.034)\end{array}$ & $\begin{array}{l}-0.07 * * \\
(0.033)\end{array}$ & $\begin{array}{c}-0.05 * * * \\
(0.003)\end{array}$ \\
\hline $\log \left(G E R_{i}\right) * B O R D E R_{i}$ & & & $\begin{array}{l}0.09 * * \\
(0.035)\end{array}$ & $\begin{array}{l}0.08 * * \\
(0.034)\end{array}$ & $\begin{array}{c}0.07 * * * \\
(0.003)\end{array}$ \\
\hline $\log \left(W A R_{i}\right) * B O R D E R_{i}{ }^{*} E U_{t}$ & & & & $\begin{array}{l}-0.02 * * \\
(0.008)\end{array}$ & $\begin{array}{r}-0.02 * * \\
(0.008)\end{array}$ \\
\hline $\log \left(G E R_{i}\right) * B O R D E R_{i} * E U_{t}$ & & & & $\begin{array}{c}0.03^{* * *} \\
(0.008)\end{array}$ & $\begin{array}{r}0.03 * * * \\
(0.008)\end{array}$ \\
\hline Regional dummies & $\mathrm{NO}$ & $\mathrm{NO}$ & $\mathrm{NO}$ & $\mathrm{NO}$ & YES \\
\hline Time dummies & YES & YES & YES & YES & YES \\
\hline Observations & 240 & 240 & 240 & 240 & 240 \\
\hline R-squared & 0.61 & 0.61 & 0.66 & 0.66 & 0.97 \\
\hline Adj. R-squared & 0.59 & 0.58 & 0.63 & 0.63 & 0.96 \\
\hline
\end{tabular}

Note: $* * * \mathrm{p}<0.01, * * \mathrm{p}<0.05, * \mathrm{p}<0.1$.

Source: own calculation.

In column (1) we report estimation results obtained for the baseline specification in which we regress the relative wages on the two main explanatory variables only: the distance from Warsaw and the distance from the German border. In the case of both variables, the estimated parameters display expected negative signs. However, only the estimated parameter on the distance from Warsaw variable is statistically significant at the $1 \%$ level of statistical significance. This means that a $10 \%$ increase in distance from Warsaw leads to a $0.6 \%$ decrease in the relative average regional wage. 
To test whether the EU accession compressed regional wage differentials, we interact the distance variables with a dummy variable that takes a value of one if the year is after 2004, the year in which Poland joined the EU. The estimation results are reported in column (2) but none of these interaction terms is statistically significant. Hence, we find no evidence that the EU accession affected regional relative wages over the sample period.

After controlling for the border effect in columns (3) and (4) in Table 2 the estimated coefficients on the distance from Warsaw variable remains statistically significant at the $1 \%$ level while the estimated coefficient on the distance from Germany variable becomes statistically significant at the 5\% level. The magnitude of the estimated impact of the distance from Warsaw remains similar, while the absolute value of the coefficient of distance from Germany increases fourfold after adding the border dummy. Hence, we can conclude that proximity to the German border stronger affects the relative wages once the border location of the region is taken into account.

The interaction terms between the distance variables and the border effects are statistically significant in columns (3) and (4) at the 5\% and $1 \%$ levels, respectively. The estimated parameter on the interaction term between the distance from Warsaw and the border effect displays a negative sign while the estimated parameter on the interaction term between the distance from the German border and the border effect displays a positive sign. These results do not change when we add the interaction terms with the EU dummy.

Finally, in column (5) we control for individual effects for particular regions. The estimated coefficients on the distance variables are statistically significant at the $1 \%$ level. Similarly, the estimated parameters on the interaction terms between the distance variables and the border effects remain statistically significant at the $1 \%$ level. The interaction terms with the EU dummy are statistically significant although at different levels of statistical significance. The estimated parameter on the interaction term for distance from Warsaw is statistically significant at the $5 \%$ level and displays a negative sign, while the estimated parameter on the interaction term for distance from the German border is statistically significant at the $1 \%$ level and displays a positive sign.

Despite the existing differences in the databases and the countries, our results for Poland are quite similar to the results obtained by Hanson (1997) for Mexico. As for the increasing returns based agglomeration, we find similar evidence as Hanson (1997) did. Those regions located near the economic center have higher wages and wages are decreasing with distance from the capital. 


\section{Conclusions}

In this paper, we have investigated the regional structure of Polish relative wages before and after Poland's accession to the European Union in 2004. Our assembled empirical evidence shows that the distance from the capital and the distance from the German border matter for regional relative wages. Thus, the empirical results are consistent with the increasing returns prediction of the NEG literature. However, the evidence for the compression in regional wage differentials following the accession to the EU in 2004 was much weaker as the integration with the European Union started long before the accession.

Furthermore, it is important to note that our sample covered only the first few years after Poland's accession to the EU and may not capture the longrun effects of the European integration related to construction of transEuropean transportation networks, which may lower the trade barriers between Poland and other EU countries. Moreover, in the future studies it would be instructive to consider also the role of foreign direct investment and migration of workers on the regional structure of wages within Poland. Finally, it would also be useful to investigate in future studies the regional structure of wages in particular sectors of the Polish economy.

\section{References}

Adamczyk A., Tokarski T., Włodarczyk R. (2009), Przestrzenne zróżnicowanie płac w Polsce, „Gospodarka Narodowa”, No. 20(9).

Alonso-Villar O. (2001), Large metropolises in the Third World: An explanation, "Urban Studies", Vol. 38, http://dx.doi.org/10.1080/00420980120061070.

Cieślik A. (2005a), The location of foreign firms and national border effects: The case of Poland, "Journal of Economic and Social Geography - Tijdschrift voor Economische en Sociale Geografie", Vol. 96, No. 3, http://dx.doi.org/10.1111/j. 1467-9663.2005.00460.x.

Cieślik A. (2005b), European integration, national border effects and the location of multinational enterprises in Poland: The case of new voivodships, "Brussels Economic Review - Cahiers Economiques de Bruxelles", Vol. 48.

Cieślik A. (2007), Wplyw umów o wolnym handlu na wielkość wymiany handlowej Polski w latach 1992-2004, „Bank i Kredyt”, No 37(6).

Cieślik A. (2013), Determinants of the location of foreign firms in Polish regions: Does firm size matter?, "Journal of Economic and Social Geography - Tijdschrift voor Economische en Sociale Geografie", Vol. 104 No. 2, http://dx.doi.org/10.1111/tesg.12017. 
Cieślik A., Hagemejer J. (2011), Evaluating the effectiveness of preferential trade liberalization in Central and Eastern Europe, "International Trade Journal", Vol. 25, No. 5, http://dx.doi.org/10.1080/08853908.2011.604298.

Cieślik A., Rokicki B. (2013), Regional wage determinants in Poland: The empirical verification of the NEG approach, "Bank i Kredyt", No 44(2).

Combes P.P., Mayer T., Thisse J.F. (2008), Economic Geography. The integration of Regions and Nations, Princeton University Press, Princeton.

Crozet M., Koenig-Soubeyran P. (2004), Trade liberalization and the internal geography of countries [in:] Mucchielli J.L., Mayer T. (eds.), Multinational Firms' Location and the New Economic Geography, Cheltenham: Edward Elgar.

Hanson G.H. (1997), Increasing returns, trade and the regional structure of wages, "Economic Journal", Vol. 107.

Hanson G.H. (2001), U.S.-Mexico integration and regional economies: Evidence from border-city pairs, "Journal of Urban Economics", Vol. 50, No. 2, http://dx.doi.org/10.1006/juec.2001.2217.

Hirschman A.O. (1958), The state of economic development, Yale University Press: New Haven.

Krugman P. (1991), Increasing returns and economic geography, "Journal of Political Economy", Vol. 99, No. 3.

Krugman P., Livas-Elizondo R. (1996), Trade policy and third world metropolis, "Journal of Development Economics", Vol. 49, http://dx.doi.org/10.1016/03043878(95)00055-0.

Misiak T., Tokarski T., Włodarczyk R. (2011), Konwergencja czy dywergencja polskich rynków pracy? „Gospodarka Narodowa”, No. 239/240(7/8).

Montfort P., Nicolini R. (2000), Regional convergence and international integration, "Journal of Urban Economics", Vol. 48, http://dx.doi.org/10.1006/ juec.1999.2167.

Myrdal G. (1957), Economic theory and underdeveloped regions, Duckworth: London.

Paluzie E. (2001), Trade policies and regional inequalities, "Papers in Regional Science", Vol. 80, http://dx.doi.org/10.1111/j.1435-5597.2001.tb01787.x.

Rogut A., Tokarski T. (2007), Determinanty regionalnego zróżnicowania płac w Polsce, „Ekonomista”, Nr 1.

Rokicki B. (2007), Regionalna konwergencja płac $w$ Polsce $w$ okresie integracji z Unia Europejska [in:] Michałek J.J, Siwiński W., Socha M.W. (ed.), Polska w Unii Europejskiej. Dynamika konwergencji ekonomicznej, Polskie Wydawnictwa Naukowe.

World Trade Organization, Trade Policy Reviews (http://www.wto.org/engl ish/tratop e/tpr e/tp136 e.htm). 